DOI https://doi.org/10.30525/978-9934-26-109-1-19

\title{
RESEARCH AND ANALYSIS OF SEMI-FINISHED PRODUCTS MADE FROM PORK AND FRESHWATER FISH
}

\author{
Tischenko V. I. \\ PhD, Associate Professor, \\ Food technology and Safety Department \\ Sumy National Agrarian University \\ Bozhko N. V. \\ PhD, Associate Professor, \\ Medical institute \\ Sumy State University \\ Shubina Ye. A. \\ Master \\ Sumy National Agrarian University \\ Sumy, Ukraine
}

Nowadays, due to the accelerating pace of life, people are gradually showing some sub-healthy conditions, so we are paying more and more attention to food health and safety. In the world food industry, healthy, safe, and nutritious food has become the focus of attention. Research on food functional ingredients and the development of functional foods has become a hot spot and development trend of food research in the world [1, p. 2].

Functional foods refer to foods with specific nutritional and health-care functions, that is, foods that are suitable for specific people to eat, have the function of regulating the body, and are not for the purpose of treatment [2, p. 94]. Its scope includes foods that enhance the body's physique; foods that prevent diseases; foods that restore health; foods that regulate body rhythms and foods that delay aging. People add active nutrients that are beneficial to body tissues to food to effectively reduce or prevent human diseases and protect the health of the body [3, p. 12].

Many studies in different countries around the world are devoted to the study of functional nutrition. In the current functional food market, there are many low-calorie, low-fat functional foods; at the same time, people are optimistic about the market for plant foods such as health teas and Chinese herbal medicines; in addition, the high-tech production and 
advanced technology production of capsules and tablets have the functionality. The development of food will get better and better. But in combination with meat products, the development of functional products is relatively weak.

Combined products can meet the needs of humans for a balanced diet. Together, they can develop higher biological value, and their sensory characteristics are not inferior to traditional products [4, p. 20].

According to statistics, in the world's meat semi-finished products market, frozen products account for the largest share, while refrigerated semi-finished products account for $40 \%$ of it. They are popular. The reasons for our increased demand for semi-finished products include $[5$, p. $50 ; 6$, p. 139].

There is not much research on the combination of pork and fish to determine its compatibility. Pork-based and fish-based studies have shown that these products are not inferior to traditional foods based on pork and beef in terms of their functional technology and sensory properties.

The purpose of our work is to verify the production of combined meat products, semi-finished products made from regional non-traditional raw materials, and research on the functional and technical characteristics of minced meat and finished products.

The information about ingredient of developed recipes is shown in the Table 1.

Table 1

The recipe of the semi-finished meat control and test samples

\begin{tabular}{|c|l|c|c|c|}
\hline № & Ingredients & $\begin{array}{c}\text { Homemade cutlets } \\
\text { control }\end{array}$ & Sample № 1 & Sample № 2 \\
\hline 1 & Pork & 30,5 & 30,5 & 25,5 \\
\hline 2 & Beef & 30,5 & - & - \\
\hline 3 & Freshwater fish & - & 30,5 & 34,5 \\
\hline 4 & White bread & 12,0 & 12,0 & 12,0 \\
\hline 5 & Breadcrumbs & 4,0 & 4,0 & 4,0 \\
\hline 6 & Onion & 1,5 & 1,5 & 1,5 \\
\hline 7 & Black pepper & 0,06 & 0,06 & 0,06 \\
\hline 8 & Eggs & 2,0 & 2,0 & 2,0 \\
\hline 9 & Salt & 1,2 & 1,2 & 1,2 \\
\hline 10 & water & 18,3 & 18,3 & 18,3 \\
\hline
\end{tabular}

The technological process is performed in fig. 1. 


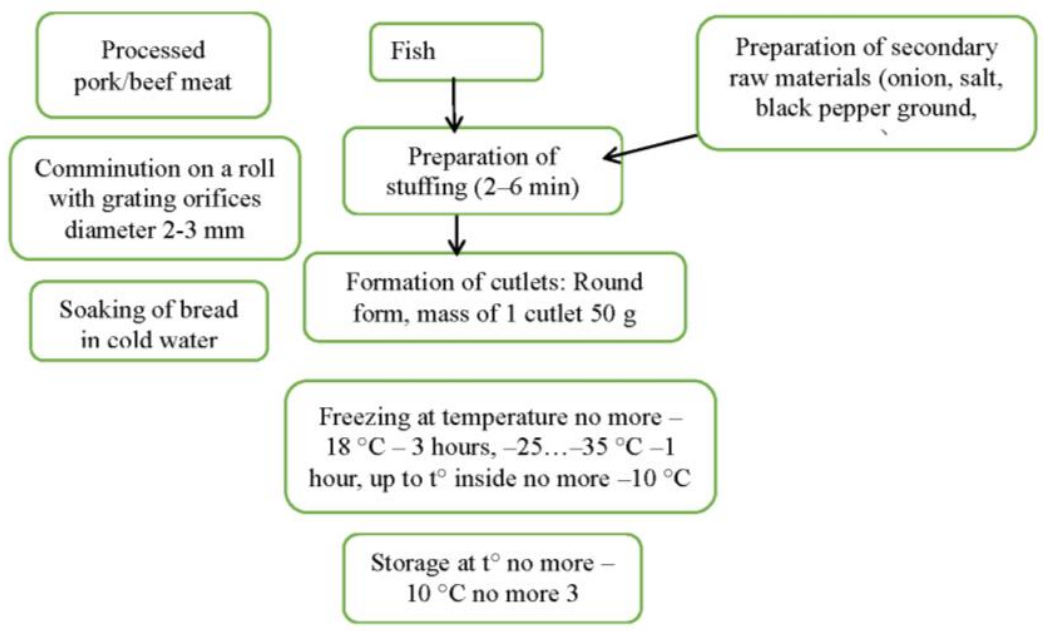

\section{Figure 1. Technical solution for processing semi-finished products}

In the course of the research, we analyzed the functional technical parameters of the semi-finished model minced meat containing products of pork and freshwater fish. The results are shown in Table 2.

Table 2

Functional and technical characteristics of minced meat samples

\begin{tabular}{|l|c|c|c|}
\hline \multirow{2}{*}{ Indicators } & \multicolumn{3}{|c|}{ Minced meat samples } \\
\cline { 2 - 4 } & Control & Sample № 1 & Sample№ 2 \\
\hline $\mathrm{W}, \%$ & $71.04 \pm 0.80$ & $72.83 \pm 0.57$ & $82.42 \pm 1.16$ \\
\hline $\mathrm{WBC}_{\mathrm{m}}, \%$ & $97.71 \pm 1.27$ & $96.75 \pm 0.70$ & $98.95 \pm 0.18$ \\
\hline $\mathrm{WBC}_{\mathrm{a}}, \%$ & $69.41 \pm 0.90$ & $70.43 \pm 0.50$ & $81.54 \pm 0.16$ \\
\hline $\mathrm{pH}$ & $5.70 \pm 0.01$ & $6.25 \pm 0.003$ & $6.73 \pm 0.12$ \\
\hline $\mathrm{WHC}, \%$ & $63.06 \pm 0.00$ & $62.85 \pm 0.00$ & $76.47 \pm 0.05$ \\
\hline $\mathrm{EC}, \%$ & $97.00 \pm 1.41$ & $98.00 \pm 0.00$ & $98.00 \pm 0.00$ \\
\hline $\mathrm{ES}, \%$ & $63.43 \pm 3.11$ & $67.03 \pm 0.51$ & $69.49 \pm 2.56$ \\
\hline
\end{tabular}

The results given in Table 4 indicate that the meat-containing semifinished products in Sample 2 have the best functional specifications. The moisture content of sample 2 was $82.42 \pm 1.16 \%$, which was higher than that of sample $172.83 \%$ and control group 71\%. Comparing Sample 1 and Sample 2, the analysis results confirmed that the combination of pork and 
freshwater fish formula can improve the indicators of WBC, EC and ES. The higher the ratio of fish-containing meat, the higher the water holding capacity and emulsifying ability of the minced meat sample.

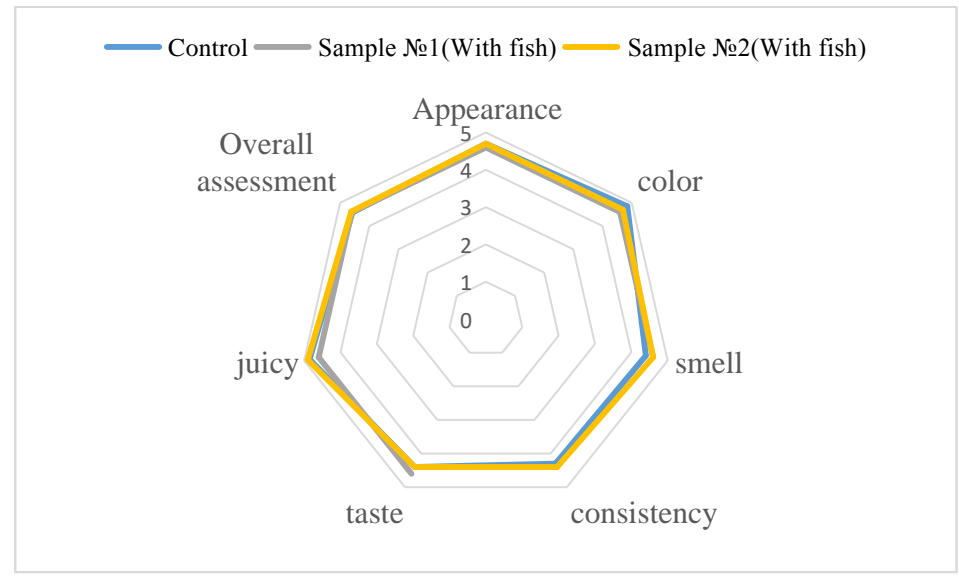

Figure 2. Outline of quality assessment

Figure 2 is the sensory evaluation results of the research samples. Figure 2 shows the outline of the sensory evaluation of the sample. Overall, the sensory evaluation of recipes using fish is better than the recipe using beef. Compared with sample 1 and sample 2, sample 2 with a larger amount of fish has better sensory parity results.

Through research and analysis, recipes that combine pork and freshwater fish can completely replace pork and beef recipes. Researching the formula of semi-finished products containing pork and freshwater fish meat, we have obtained products with high functional and technical characteristics: water-binding capacity is as high as $82.415 \%$, water retention capacity is as high as $76.47 \%$, emulsification capacity is as high as $98.0 \%$, and the emulsification stability is as high as $69.49 \%$. According to the data obtained, the moisture content in the sample depends on the composition of the formulation. Compared with the traditional type of combined semi-finished meat products, its function, technology, and sensory characteristics are higher. Therefore, functional semi-finished products made from the combination of pork and freshwater fish meat can be developed. 


\section{References:}

1. Kraus, A. Development of functional food with the participation of the consumer. Motivators for consumption of functional products. International Journal of Consumer Studies. 2015. Vol. 39 (1). P. 2-11.

2. Granato, D., et al. Functional foods: Product development, technological trends, efficacy testing, and safety. Annual review of food science and technology. 2020. Vol. 11. P. 93-118.

3. Yerlikaya, S., et al. A multidirectional perspective for novel functional products: in vitro pharmacological activities and in silico studies on Ononis natrix subsp. hispanica. Frontiers in pharmacology. 2017. Vol. 8. P. 1-14.

4. Maitan-Alfenas, G., Casarotti, S. Enzymes and dairy products: Focus on functional products. Microbial cultures and enzymes in dairy technology. IGI Global, 2018. P. 1-22.

5. Bozhko, N., et al. Development of meat-containing minced semifinished products based on the locally produced raw materials. EasternEuropean Journal of Enterprise Technologies. 2018. Vol. 4 (11). P. 49-54.

6. Божко Н.В. В.I. Тищенко, В.М. Пасічний Дослідження споживчої та біологічної цінності м'ясомістких посічених напівфабрикатів. Наукові праці Національного університету харчових технологій. 2020. Т. 26. № 1. С. 134-141. 